\title{
When Cultures Divide
}

\author{
Writing Public History in Latin America
}

Marivic Wyndham and Peter Read

\begin{abstract}
We two Australian public historians recently published a history of memorials in Santiago, Chile, to the victims of the Augusto Pinochet dictatorship, Narrow but Endlessly Deep: The Struggle for Memorialisation in Chile since the Transition to Democracy. Our different upbringings and experiences (one a migrant from Cuba, the other Anglo-Australian) produced disagreements as to how we should interpret the memorializations. In particular, the foundational narratives of Cuba and Australia in which we were raised affected our differing interpretations. The article explains these differing foundational narratives and then cites examples of textual disagreements and how we resolved them. We believe that this challenging interrogation of lifetime values improved the monograph and may offer insights for other cross-cultural collaborations.
\end{abstract}

KEY WORDS: public history, cross-cultural awareness, memorials, Pinochet dictatorship, collaborative authorship

The Chilean general Augusto Pinochet seized power from the government of Salvador Allende on September II, I973. Pinochet remained in office for seventeen years, by which time his regime was responsible for the deaths of at least three thousand left-wing activists and the torture of more than thirty thousand. ${ }^{1}$

In 2004, we two Australian historians, Marivic Wyndham and Peter Read, began research towards a monograph on the public memorializing of seven infamous sites of torture and execution in Santiago. This work, published twelve years later as Narrow but Endlessly Deep: The Struggle for Memorialisation in Chile since

I The report of the National Commission for Truth and Reconciliation in Chile, known as the Rettig Report, named 979 detained or disappeared persons and I,3I9 others politically executed. Amnesty International's figure in 1996 totaled 3,I07 victims of disappearance and death. Report of the National Commission for Truth and Reconciliation ("Rettig Report"), Santiago, 2004, http://www.usip .org/files/resources/collections/truth_commissions/Chile9o-Report/Chilego-Report.pdf; Report of the National Commission on Political Imprisonment and Torture ("Valech Report"), November 29, 2004, https://www.usip.org/publications/2003/og/commission-inquiry-chile-03.

THE PUBliC HISTORIAN, Vol. 40, No. I, pp. 34-53 (February 20I8). ISSN: 0272-3433, electronic ISSN 1533-8576. (C) 2018 by The Regents of the University of California and the National Council on Public History. All rights reserved. Please direct all requests for permission to photocopy or reproduce article content through the University of California Press's Reprints and Permissions web page, http://www.ucpress.edu/journals.php?p=reprints. DOI: https://doi.org/Io.I525/tph.2018.40.I.34. 
the Transition to Democracy, ${ }^{2}$ traced the attempts of survivors, their families, colleagues, and supporters to memorialize the experiences of torture, terror, and state murder at these sites, several of which are now recognized as International Sites of Conscience. ${ }^{3}$

No sooner had we begun writing than the consequences of our cultural upbringings, so different that they might almost be said to be in opposition, became apparent. Marivic migrated to Australia from Cuba in 1976 and is a four-generation Spanish descendant. Peter is a native-born Anglo-Australian of four generations. We met as tutors in Australian history in 1992 at the Australian National University and began researching the public history of Cuba in 1996. In the following decade we collaborated to produce a number of articles on the public history of Cuba. Commencing research in Chile in 2004, we collaborated on analyses of postPinochet Chilean public history before beginning work on the monograph. In this article we first analyze some opposing elements within these two national cultures of the authors. We then discuss the ways in which, in our Cuban and Chilean research, the differences were revealed, and the compromises that we were forced to make in interpreting the public history of the memorials.

Scholars from the American Frederick Jackson Turner to Australia's Russell Ward have for more than a century tried to identify and analyze the cultural shaping of national values. ${ }^{4}$ Today's more sophisticated analysts still can find it challenging to mine the bedrock of values so deeply implanted in one's own cultural soil that it is impossible to discern exactly when or how they were imparted. Indeed, as we suggest here, a failure to separate conviction from what we may have uncritically accepted as a child may not become apparent until contrasted with the differing cultural values of another country-or collaborator.

\section{Family Cultural Narratives}

Marivic: Political violence is part of my family history. Two grandparents were mambises, Cuban patriots who fought in the late nineteenth century against the Spanish in a bloody and violent war of independence. In the early I930s my parents met as student revolutionaries in a struggle against President Gerardo Machado, who was threatening to destabilize Cuba's always-fragile democracy. While a student at the University of Havana, my mother, Maria Aurora, led a hunger strike in

2 Peter Read and Marivic Wyndham, Narrow but Endlessly Deep: The Struggle for Memorialization in Chile since the Transition to Democracy (Canberra: ANU Press, 20I6). The book is reviewed in this issue.

3 "Sites of conscience" is a term used by the human rights movement to describe centers of torture and execution, usually carried out by the state, which have been memorialized or interpreted. The International Coalition of Sites of Conscience was founded in 1999. See https://www .sitesofconscience.org/en/home/.

4 Frederick Jackson Turner, "The Significance of the Frontier in American History," The Annual Report of the American Historical Association (1894), II9-227; Russell Ward, The Australian Legend (Melbourne: Oxford University Press, 1958). 
jail after she and fellow revolutionaries suffered torture by the secret police. My father, Isauro, an engineering student, was a prominent member of the militant wing of the student movement. As an old man, he would become wistful remembering his allotted task to produce and deliver a bomb to blow up a congregation of mourners at a political funeral. The bomb failed to explode. Sixty years later, he was still lamenting the lost opportunity to make a resounding political statement against the dictatorship. His mantra was: "If you're prepared to kill for a cause, you must also be prepared to die for it." One of the least challenged themes of my, and my family's, psyche were the sentiments of the Cuban national anthem that we would regularly sing at school:

Hasten to battle, men of Bayamo,

For the homeland looks proudly to you.

Do not fear a glorious death,

Because to die for the country is to live. ${ }^{5}$

This was and is the blood that runs in my veins.

Cuba's political instability in the I95os meant that violence remained a continued menace in my life as a child. Exilio-exile-was one of the first words I learned, for abandoning my home and country were among my earliest experiences of childhood. By 1956 we had already endured two abrupt, though temporary, exits, one in Mexico and one in Miami. Returned to Havana in I955, I grew accustomed to the regular political emergencies, the ambushes, kidnappings, and assassinations. At school in 1958, with other classmates whose parents were concerned for their safety, I would regularly be summoned by the school principal to the front office and be rushed home until the latest threat subsided. Since we knew whose fathers were in the military, police, or government, I could always tell what sort of emergency it was by which classmates were summoned!

A second foundational strain that I unconsciously absorbed was a lament for the unfinished Cuban revolution born in the war of independence against Spain in the nineteenth century. A I940s song by the famous interpreter of Cuban rural life, Guillermo Portabales, began:

Oh beautiful adorable Cuba, why do you today suffer such rupture?

Oh my motherland, who would have said that your blues skies would be clouded by tears?

$\mathrm{Oh}$ in the whispering of the palms, you can hear the echoing voice of suffering calling us to love

In musing on your ardent, burning sun, your resplendent green fields, I think of the time that is now gone, Cuba. ${ }^{6}$

5 Cuban national anthem, "La Bayamesa," https://www.lyricsondemand.com/n/ nationalanthemlyrics/cubanationalanthemlyrics.html.

6 Guillermo Portabales, "Lamento Cubano" (translation by author), https://www.letras.com/ guillermo-portabales/768579/. 
Even now those words evoke in me a wistful nostalgia for a promise of a truly independent Cuba, which never eventuated.

In I960 my family left for our third and last exile, in Miami, together with hundreds of thousands of fellow Cubans fleeing the Communist revolution. My father had already gone at the dawn-literally-of the revolution on January I, I959, while, in the early months, my mother, two sisters, and I hid in a safe houseexpecting the barbudos to come looking for us. They never did, and we eventually returned to the family home. We joined my father in exile eighteen months later. I was barely eleven years old but I will never forget the full body search at Havana airport on departing for Miami.

In Miami I began my "American" education in earnest. "God Bless America," a song we had sung in Cuba as "Dios Salve a América," suddenly took a surprising turn. In Miami and the rest of the nation, "America" meant the United States, not the American continent, as our Spanish version had assumed. Never mind, I was working hard at belonging in my adopted country and learning to sing all the verses of their many patriotic songs. A favorite was:

I like the United States of America

I like the way we all live without fear

I like to vote for my choice, speak my mind, raise my voice

Yes! I like it here.

As a teenager I lived through more political turbulence, this time the civil rights movement, the Vietnam War protests, and the assassinations of John F. and Robert Kennedy and of Martin Luther King Jr. In my own family circle, it was the loss of our island nation and the demon who had taken it from us-Fidel Castro-that were the all-consuming passions. I remember fondly many a bus journey with my father to Washington, DC, to join Cuban exiles insisting that the US government "send in the marines" to liberate our island. My family culture of freedom fighters and the normative violence of the United States intertwined with a passionate anticommunism and the trauma of an unfinished revolution in a country lost forever. The implications of such a mix for my intellectual development did not reveal themselves for many decades.

In the national mythology of my country of birth, our soil cannot be anything but blood-drenched.

Peter: My Australia, which has never experienced civil war, revolution, or a war of independence, invested me with rather less aggressive values. ${ }^{7}$ My cultural antecedents are rooted in the Australian foundational narrative of the Australian and New Zealand Army Corps (Anzac), in which Australians, with other British

7 Since the I980s, Australian historians have opened a fiery debate about the "frontier wars," which concluded in wide agreement that Australians had ignored the long and violent campaign against Aborigines. This historical preoccupation came too late, however, to affect Read's adolescent cultural formation. 
Empire troops, in April I915 attempted a seaward invasion of Turkey. Australian myth makers since that time have magnified and glorified the account into one of the new nation rushing to Great Britain's aid in its hour of need, demonstrating its valor and participating in a glorious military episode. Somehow in the telling the episode was made the more poignant by ending in the ignominious withdrawal of the Anzac troops.

The trope of glorious failure was no Australian invention but ran deep in late Victorian and Edwardian England. In 1897, Rudyard Kipling compared the possible end of British power to the ruins of Nineveh and Tyre. ${ }^{8}$ In I9II, Robert Falcon Scott heroically died in his failure to reach the South Pole. In I9I2 the "band played on" aboard the sinking Titanic. The famous British lament for the fallen soldiers of the Great War, "O Valiant Hearts," the less jingoistic verses of which (one and two) are still sung at the annual Anzac Day Dawn Service at the Australian War Memorial in Canberra, names no enemies. In April 2017 my eldest grandson and I sang it together. Similarly, we empire soldiers fought "to save mankind" rather than against a specific enemy. As I reflect upon it now, the equation of the hymn with Scott and the "Anzac legend" is striking:

Splendid you passed, the great surrender made,

Into the light that nevermore shall fade;

Deep your contentment in that blest abode,

Who wait the last clear trumpet-call of God. ${ }^{9}$

In 1922, as the Australian "Anzac legend" was beginning to consolidate, the British author J. M. Barrie praised Scott's courageous but glorious failure:

Courage. I do not think it is to be got by your becoming solemn-sides before your time.... Look to it that what you are doing is not merely toddling to a competency. Perhaps that must be your fate, but fight it and then, though you fail, you may still be among the elect of whom we have spoken. ${ }^{10}$

Even within the Anzac tradition, and in sharp contrast to Cuba's mambises, one of the strongest themes in Australian patriotism is that of antihero. Among the most celebrated individuals at Australia's "baptism of fire" at Anzac Cove was not a warrior but the private soldier, Simpson, who rescued wounded men on his donkey until he was killed himself.

In 1962, five decades after Gallipoli, I was shaped by the culture of the comfortable professional middle classes. In my private school, in the ig6os, I absorbed the story of the brave band on the Titanic. I learned by rote and recited part of Barrie's speech in the school's ig6o oratory contest and recalled it so clearly that in

8 Rudyard Kipling, "Recessional," I897, reprinted here: https://www.poetryfoundation.org/ poems-and-poets/poems/detail/46780.

9 John S. Arkwright, "The Supreme Sacrifice," in The Supreme Sacrifice and Other Poems in the Time of War (London: Skeffington and Son, Ltd., 1919), 17-18.

Io J. M. Barrie, Courage (New York: Cosimo, Inc.,) 2005, 3 I. 
2016 I found it using Google in just a few seconds. I joined in "O Valiant Hearts" in chapel, and on Anzac Day 1962 read to a thousand-strong audience a stirring address that began:

On this day, forty-seven years ago, men of the Australian and New Zealand Army Corps landed on the beaches of Gallipoli. In so doing they wrote upon the pages of their country's history words that would endure.

How proud I felt of the four members of my family who "fell" for their country, three in the First World War and one in the Second, from which one might infer a Cuban-style pride in sacrifice by military valor. Their deaths, in fact, numbered more than Marivic's family losses, which were none. Yet my, and my family's, perception of military enlistment was more of a Cincinnatus-like temporary abandonment of chosen professions to fight for as long as duty deemed necessary before returning, uncelebrated, to civilian life. I was too young to recall how my great-uncles Harold Olver and Harold and Brian Antill Pockley were remembered, but the death of my uncle John Read at Singapore in 1942 was a sorrow so profound in my adolescence that it could scarcely be alluded to. Around it always hovered the unspoken lament (since Australia did not conscript men for service overseas in either war), "if only he hadn't (voluntarily) enlisted."

Perhaps the strongest contrast between Australia's and Cuba's sons and daughters, and our childhood educations, was the contrasting default positions towards the authority of the state. Most Cuban young people, and Marivic's parents, until the time of Castro, assumed that in the likely event of internal civil disturbance, such as a government refusing to retire at the end of its term, the right course of action would be to enlist in a paramilitary unit to restore the republic. In contrast, facing an external threat, my uncles and great uncles fought in uniform for the government and, in the First World War, for empire as well. In my national anthem, Australians celebrated, then and now, nothing more stirring than a bountiful nature presented to them rather than achieved through sacrifice. We were not called upon to do anything but accept the environmental gifts and "advance."

Australians all let us rejoice,

For we are young and free;

We've golden soil and wealth for toil;

Our home is girt by sea;

Our land abounds in nature's gifts

Of beauty rich and rare;

In history's page, let every stage

Advance Australia fair. ${ }^{11}$

We sing that every school assembly at my grandson's primary school.

II Australian national anthem, “Advance Australia Fair," verse I, http://dfat.gov.au/about -australia/land-its-people/Pages/australias-national-symbols.aspx. 


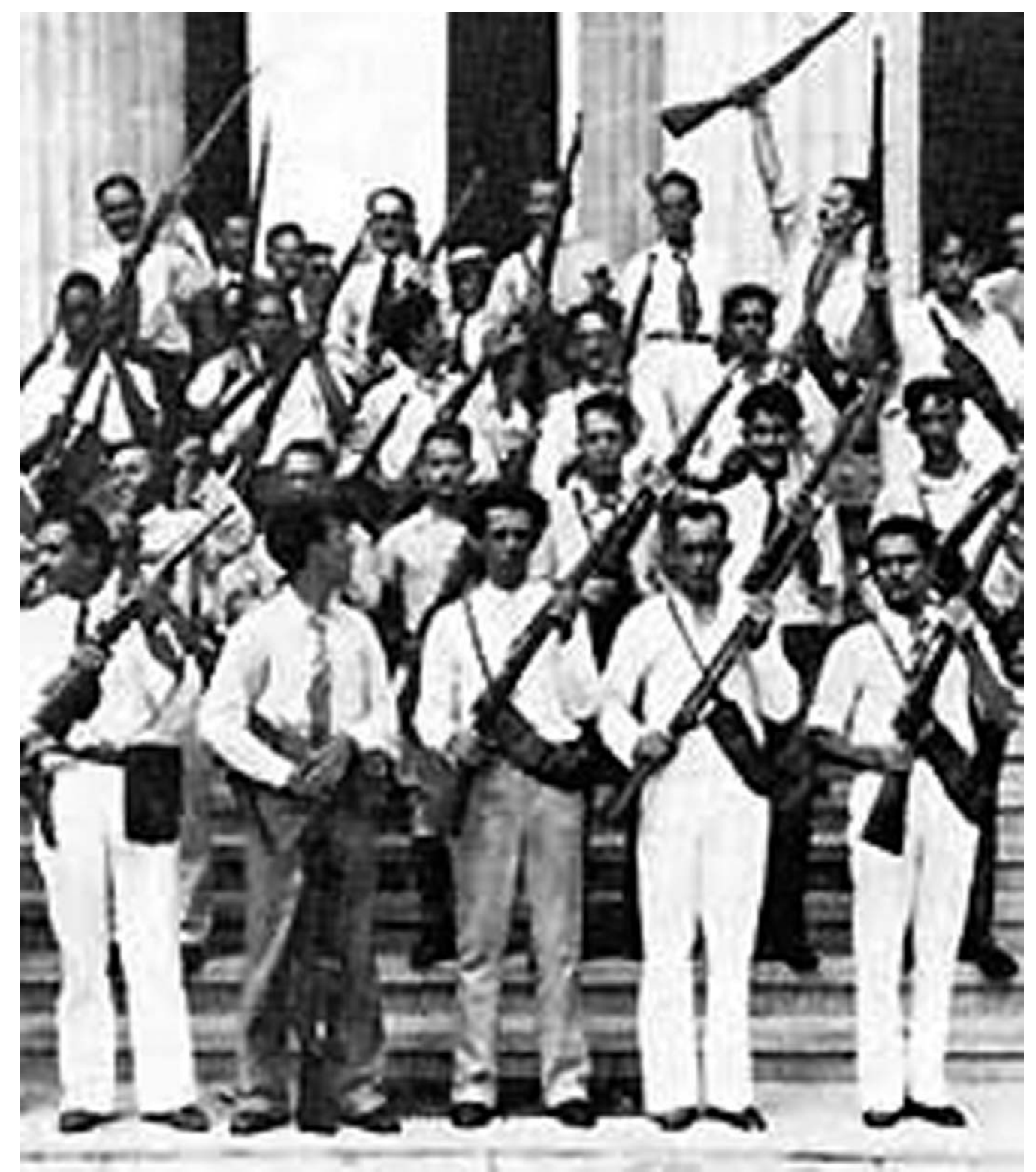

Armed students, Cuba, 1933. (Image courtesy of author)

Non-Aboriginal Australians have fought all their wars overseas. Even its first sacred site-Anzac Cove-is in Turkey.

Writing and Resolving Difference

Writing about a single event separately is, of course, much easier than finding agreement, as co-authors, on a single interpretation. To illustrate how two such differing interpretations can be equally valid, though unresolved, we cite some 


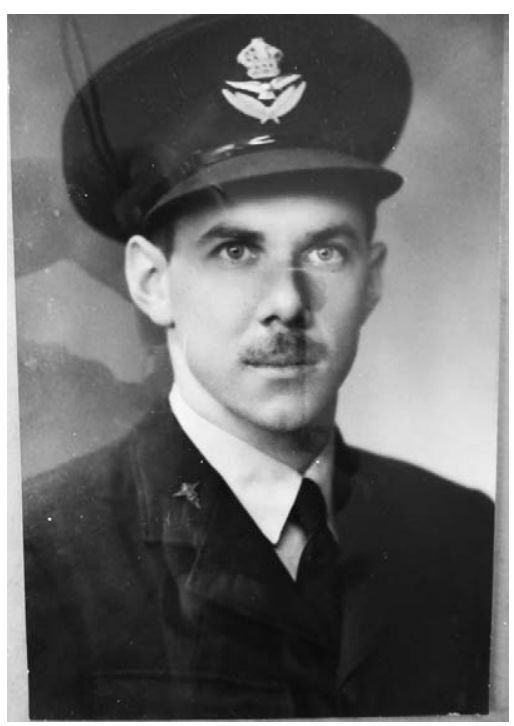

Flight Officer F. H. Read (Read's father), Royal Australian Air Force, c. I946 (Image courtesy of author)

points of disagreement in our descriptions drawn from the public history of Cuba and Chile. This is how each of us represented two incidents, one from Marivic's childhood as a Cuban exile, and one that we both experienced on a trip to the island. As we wrote about these events separately, we were able to express our divergent understanding of them without having to reconcile the two.

Marivic: As an eleven-year-old girl following my parents into exile to Miami in I960, I understood material loss very well, from having to leave behind my adored three-foot pink toy rabbit as we packed for Miami in I96o because she was too big for my suitcase, to the loss of my uncle Che's beautiful beach mansion at Jibacoa, a seaside village two hours' drive from Havana. He had simply to abandon it as he left Havana on the first day of the revolution, January I, I959.

My aunt Marianita and her family would follow a year later. Yet just a month after the revolution, she stormed back to Jibacoa to reclaim her beach house. With her was her son, and I-for some reason-decided to tag along. Here is how I described it in a 2009 article:

The early warnings of what awaited us came as we approached the coastline of [Jibacoa]. It was devastating. Clotheslines, intimate clothing and rubbish lay everywhere about the beach. This was not the beautiful pristine place we had left a mere month ago. It was like a horde of barbarians had been let loose here. The guardhouse, we noticed, was empty. Approaching the Big House, we saw the unkempt garden, and more ominously, Felipe, María and the other staff were nowhere to be seen. We approached the front door. Marianita was in a rage and wanted explanations. Her key to the house no 
longer worked. She knocked on the door and there in front of us was Raquel, one of Marianita's personal maids of many years, blocking our entrance. There was no respectful greeting, as in the old days. Instead Raquel uttered the words that have resounded in every revolution in every age and in every country, Señora, ésta no es su casa. "Madam, this is not your house," followed by the sound of a slamming door. It would not open again for us. ${ }^{12}$

Peter: I recounted the same story, in quite a different context, in a chapter of a book about how non-Aborigines form emotional attachments to Australia. Unable to match the agonizing emotional loss of the family home, I wrote much more prosaically:

Marivic was nine years old when Castro seized power in Cuba. One of her clearest memories was visiting Jibacoa, the seaside mansion of her uncle who had already fled with her father to the Dominican Republic on the first day of the revolution. It was less than a month later. Her aunt knocked; a former maid appeared to stare at the former owner. "Señora, ésta no es su casa" (Madam this is not your house). And she slammed the door. Marivic's mother and three daughters, of whom Marivic was the youngest, left Cuba two years later to join her father, by now in the United States. ${ }^{13}$

We had thus side-stepped the emotional dichotomy by recounting the same event in different contexts. We adopted a similar strategy following an experience even more stark that we shared in 1996.

At the time, during Castro's "Special Period" (as he termed the time of economic hardship following the withdrawal of Soviet aid to Cuba) of the I99os, the National Cemetery in Havana was very ill cared for. Tombs had been robbed, people slept rough in mausolea, graves were exhumed after two years and their contents casually shoveled into wheelbarrows. Exploring the cemetery, we entered the Tomb of the Reporters, which to me bore a decidedly sinister-looking aspect. I wrote:

The generous proportions and elegance of the chamber mark the interior as well as the glass ellipse [the outside structure] as one of the most exquisite mausoleums in the land. A first glance reveals what the tomb was meant to be. A second glance reveals what it now is. A third pinpoints the nightmare of all those charged with the care-across many continents and many centuries-of the revered and solemn dead.

Some of the spaces intended for coffins are empty. Were they once filled? Several others have been broken into with a pick or a sledge-hammer. Some appear to contain whole coffins, others only black and shattered remains.

I2 Alejandra Morena and Roberto Milanes [pseudonyms], "Knowing the Place for the First Time: A Cuban Exile's Story," PORTAL: Journal of Multidisciplinary International Studies 6, no. I (January 2009): IO-II.

I3 Peter Read, Belonging (Melbourne: Cambridge University Press, 2000), I38. 
Pieces of human body lie athwart the smashed coffins or on the floor. What looks like a ribcage is half inside a coffin, half out. Small and large pieces of bone and dark flesh are scattered in the shadows. Does this appalling desecration flow from some independent motive? The deep silence, the heavy air, the threatening lowering violence, the enigmatic texts, the shadowy light, the baleful ambience, the spiritual menace which threatens at any moment to materialize. ${ }^{14}$

Marivic reacted to the explorations of the tomb very differently:

On this first re-visit I had chosen to ignore the dire warnings of my family in Miami of the terrible things I would find in the island: communists, for one thing! Traitors who'd chosen to stay and support the regime, rather than leave for exile. No, I was returning in a spirit of solidarity with those left behind. Those who'd stayed and lived and loved and suffered through those 36 years I'd been away. I had no idea what awaited me, but I felt sure it would be healing and joyous and the right thing for me to do.

What I saw on that first underground floor were skeletal human parts-many heads-just lying there. My immediate reaction was to rush to them and hold them close. It was then-and remains after many subsequent visits to Cubathe most profound moment of reunion and reconciliation with the Cuba I had left behind. These dead people's parts belonged to fellow Cubans who had chosen to stay behind-as perhaps I should have-and live their lives in a country I had abandoned. I felt an immense sense of gratitude to them for being there to greet me-and also a terrible sense of guilt. Holding them seemed-quite irrationally-to be an act of forgiveness on their part. It seemed to fill in the gaps of my long absence. Had I not left 36 years before, I might have known these people. Our paths might have crossed in the streets, in the workplace, at the beach. They might even have become members of my extended family. I would have gladly stayed with my fellow Cubans that night in that forgotten part of Colon's Cemetery. ${ }^{15}$

Anger at the "nationalization" of a family home, or sorrow and guilt felt among the remains of the dead are human emotions so profound that they cannot, perhaps, be shared by a mere onlooker. Writing separate accounts of the same event seemed the more attractive and satisfactory option. Yet our widely differing emotional responses should have alerted us to problems we would encounter in writing about the intellectual as well as the emotional recent public history of another Latin American country: Chile. Coauthors of single monographs, of course, cannot

I4 Peter J. Read, “And the Dead Remain Behind," Cultural Studies Review II, no. I (March 2005): IIO-2I.

I5 Peter Read and Marivic Wyndham, paper presented at the conference "Judging the Past in a Post-Cold War World," University of Sydney, September 2015. 
present alternative versions of the same event. We now move to some of the issues that arose when we had to negotiate our way through some real dilemmas.

\section{Writing Narrow but Endlessly Deep}

In the introduction, before the main problems of interpretation had surfaced, we positioned ourselves, to our English-speaking target audience, as a unit. ${ }^{16}$ In discussing the advantages that our perspectives as foreign historians might bring to the study of Chile, we wrote, "We believe that the status of overseas historian, that is, unassociated with any particular interest group that any Chilean is likely to be, has given us considerable freedom."17 More perceptively we could have asked, "What might be the contribution of two Australian historians, one a Latina sharing a common culture of unfinished revolution, machismo, and dedicated political action among those about whom she was writing, and the other an Anglo-Australian taught to believe that his country's internal history had been almost entirely peaceful, and that its highest civic virtue was incremental change?" In an attempt at evenhandedness, in the introduction to Narrow but Endlessly Deep we explained:

Our intention in this book is not to dwell on the politics of the coup itself. It is as legitimate to celebrate the heroism of Allende's last radio address from his besieged office in the presidential palace La Moneda, as it is to cite figures of the plunging economy and strike-ridden chaos of his regime. ${ }^{18}$

Peter: I argued that such a declaration is common in Australia in an academic text purporting to thoughtful balance; yet the statement would be anathema to many older Chileans to whom there is only one "legitimate" side. Most Australian historians stand somewhere left of center but, having seen Cuba firsthand, I could sympathize with the Chilean conservatives who wanted to prevent Chile from becoming a second Cuba. At the same time, while not abhorring communism as much as Marivic, I was horrified by the notion of a coup against even the worst elected government. Somewhat removed from the Latin American culture of dedicated patriotism, my instinct as a historian was to contextualize the Chilean struggle as a localized illustration of a global ideological Cold War conflict.

Marivic: From the start I felt uncomfortable with this disclaimer. Revolutions, killing, and being killed for an honorable cause belonged to the political landscape

I6 Outside Australia, the expected readers were public historians, human rights activists, and Latin America observers in the United States and Great Britain. A Spanish translation of the book, Sin Descansar, en mi Memoria (Restless, in my memory) was published in September 20I7. This edition carries an extended preface addressing the issue of culturally translating such basic terms as "communist," which carries quite different overtones in Australia, the United States, and Latin America.

I7 Read and Wyndham, Narrow but Endlessly Deep, I7.

I8 Ibid., I8. 
of both my family and the national culture of my country of birth. Just as my parents had rejoiced, in their student revolutionary days, in the sacrifices they were prepared to make to protect their country from dictatorship, so in school I absorbed Cuba's glorious deeds committed by those prepared to fight for its independence, retold so often that it was difficult to separate family tales from Cuban history. Such stories shaped my senses of moral and physical courage, patriotism, honor, sacrifice, and manhood-the essence of Cuban identity. I began to realize that the post-Pinochet struggles signified more to me than a narrative of the Cold War alone. Our Latin American revolution was unfinished. Our hard-won independence from Spain had been frustrated by yet another empire-the United States-which rendered our war for independence a work in progress. I could not be "only" an Australian historian. A Latin American is born a patriot forever, and to be patriotic is to continue the struggle for that elusive independence. The deadly Cold War ideology that has blighted Latin America since the 1950s, and is the subject of our monograph, to me obscured the continuing war of independence for which no sacrifice was too great. So I felt really divided between the need to demonstrate evenhandedness in my approach to Allende and Pinochet and the need to position myself as a partisan standing within the broader Latin American theme of unfinished revolution in which Allende's attempt to rid his country of foreign economic domination had played a significant and glorious role. Mindful of the book's academic Australian readers, I consented to the disclaimer. But I never was altogether happy with it.

Nowhere did this tension between us become more manifest than in the chapter that focused on the attempt of the radical left-intellectual party, the Armed Revolutionary Movement known as el MIR, to establish its primary celebratory memorial in Santiago's downtown. We called it, rather provocatively, "Last Stand of the MIR: Londres 38." Here we detailed how the MIR tried to have itself included within a government-sponsored site of conscience, a building used for detainment and torture known as Londres 38 (that is, 38 Londres St.), where most of its most prominent members had suffered horribly. The MIRistas were not, in fact, very violent in physical terms, but their ideology was defiantly Marxist-LeninistGuevarist. Their reputation as middle-class idealist subversives caused them to suffer more in terms of political executions, disappearances, torture, and exile than any other political movement. A MIR commander estimated that between I,500 and 2,000 MIRistas had been killed out of a membership of ro,ooo, equaling between one-half to two-thirds of all Chileans killed during the Pinochet period. ${ }^{19}$ Because of their radicalism they were not universally admired by other leftist parties. Whereas the Communist Party, for instance, stood for the democratic exercise of workers' power, the MIR claimed that all the other leftists, including

I9 Günther Wessell, Los Allendes: con ardiente paciencia por un mundo mejor (With burning patience towards a better world) (Madrid: Editorial Tébar, S. L., 2004). 
the Communists, had prostituted their revolutionary essence by leading the workers into an electoral and parliamentary swamp. Following Che Guevara, the MIRista mission was to lead the working class and the exploited masses towards socialism and national emancipation, that is, towards a Chile composed of Guevarist-style collectives.

Unsurprisingly, successive post-Pinochet governments have been less than enthusiastic in sponsoring the physical memorialization of a movement that, however heroic, had dedicated itself to the end of free elections. Nevertheless, since 2003 a collective of MIR survivors have sought to establish the notorious torture and extermination site Londres 38 as its principal memorial. They were well justified. Of the ninety detainees thought to have been murdered within the building, probably three-quarters were MIRistas. Memorial proposals from the group ranged from silent empty rooms for solitary mourning and contemplation to a café selling postcards. Complicating the MIR's effort were the government's intention to turn the site into a human rights center and the attempt by rival left collectives to claim the building for their own purposes of memorialization. An ugly confrontation took place in what had been Londres 38's detainee holding center on the day in 2010 when the building was open to the public for the first time. ${ }^{20}$ Ultimately the MIR lost the fight; the government insisted on control and forced any exhibitions by the nongovernment collectives, including the MIR's, into a temporary space outside the building.

Peter: In the interpretation of the struggle, I was a little out of sympathy with the MIRistas who had aided, but also destabilized, the government of Salvador Allende that Pinochet overthrew. Although in awe of the extraordinary courage of some MIRistas, especially among those who chose to return to Chile to continue the armed struggle after being granted exile, I ended the chapter on their attempt to memorialize themselves at Londres 38 rather coolly:

What had gone wrong since the optimistic days when the [right wing] O'Higgins Institute finally left the building? Like the equally emblematic National Stadium, the political left had been routed by the Concertacion's [i.e., successive post-dictatorship center-left governments] own interpretative purposes. Bedevilled by internal divisions between its many claimants, the grieving families had been outmanoeuvred. By 2012 it seemed evident that the decade-long negotiations between state and collectives had been settled decisively. The history and politics of memorialisation of Londres 38 , reflected so eloquently in the constantly changing signage, pointed to how the state had been able to turn the divisions in the left to its favour. ${ }^{21}$

20 Marivic Wyndham and Peter Read, “The Day that Londres 38 Opened Its Doors," Universitas Humanistica 7I (20II): 193-2I2.

2I Read and Wyndham, Narrow but Endlessly Deep, IоI-2. 
Marivic: I was unhappy with this peroration: too uncommitted and culturally not Latin American enough. Yes, the MIRistas may have allied themselves to Castro's revolutionary agenda in Cuba, pronounced themselves Marxist-Leninist, and fought and died for a hopeless socialist utopia. Yet like the MIR, my parents had also been student revolutionaries. The MIRistas wanted another Cuba, yes, but even though I hated Castro and everything he stood for, I interpreted the deepest bedrock of the MIR not to be ideological in terms of left versus right but as a patriotic, nationalist movement answering the call for independence several centuries old. My unfinished revolution was led by Jose Martí, Chile's by Manuel Rodriguez and Arturo Prat. All, from their graves, continued to demand sacrifice. Chile seemed as exploited by American or Soviet political and economic interests as Cuba, as surely as the whole continent had once been dominated by Spain. To me, then, the MIRistas were twentieth-century embodiments of all those who had killed and died for the cause of independence in Latin America for more than two centuries. I added a salute to the young MIRistas to the account as the final paragraph of the chapter. It read:

George Orwell wrote of the Spanish Civil War, "No one who was there in the months at a time when people still believed in the revolution will ever forget that strange and moving experience." MIRistas believed in a version of that same revolution that, similarly, failed. Deprived of both physical home and physical memorial, the MIR thereafter took refuge in rehearsing its pride in the stirring ideals and selfless comradeship of a generation prepared to die for its beliefs, a brief flowering of a conviction that the world could be and should be changed by dedicated young people. By 2012 , though, that matchless time seemed another universe. ${ }^{22}$

The interpretation of torture became a related topic about which we culturally diverged. I had witnessed, as a ten-year-old, the executions by firing squad of the followers of Fulgencio Batista shown on television in the first months of the Castro regime. ${ }^{23}$ My Cuban school history texts were illustrated by drawings of heroic battles, murders, and executions. I had, long ago, confronted the realities of political repression, summary detentions, torture, and execution, but naturally remained sensitized to the appalling crimes committed by Pinochet's terrorist Chilean state. Torture victims were individuals of conviction and valor, prepared to confront the barbarous cruelty of the security forces.

The focus of our discussion on torture was the best known of all the Chilean sites of conscience, Villa Grimaldi, an eight-acre former mansion outside Santiago. It was here that more than two hundred detainees had been disappeared and where the most infamous prolonged tortures on the electric grill known as the

22 Ibid., I02. Londres 38 now serves as a state-sponsored museum and human rights center in which the persecuted political parties are not separately identified.

23 Fulgencio Batista was the Cuban president who fled on January I, I959, and died in exile. 
parrilla had taken place. The question of what should and should not be displayed in Villa Grimaldi's exhibitions and signage, revolving around whether it should be memorialized as a park of horror or a park of peace, has been endlessly and often angrily debated by survivors and supporters since the park was opened to the public in 1997. Information provided by survivors to visitors has varied over twenty years, ranging from quite explicit accounts of torture, to today's self-guided tour in which graphic description has been almost eliminated. Neither the displays nor the interpretations have ever been satisfactory to all the stakeholders, while the debate is now complicated by the evident need for the education of visiting schoolchildren who know almost nothing about either Allende or Pinochet.

Peter: As a historian of Aboriginal Australia, I am familiar with the casual though deadly settler violence of my country, yet the fact that Pinochet's regime enacted torture as much to intimidate and punish Allende's supporters as to extract information I found deeply disturbing. But believing that readers could not make a judgment on our interpretation of the site unless they were fully informed of what had actually occurred, we resolved not to avoid a detailed account of torture. Against the advice of the publisher's Political Science Publications Committee, we decided not to spare our readers, or ourselves:

Gladys Díaz Armijo was a MIRista and well-known journalist who reportedly spent more time in Villa Grimaldi-three months-than anyone else.

Immediately on arrival at Villa Grimaldi she was beaten. An unidentified voice snarled, “Leave this bitch for me.” Her blindfold was caked in old blood: “Don't worry about it, you won't be getting out alive anyway." Strapped to the parrilla, she once regained consciousness to recognise the same man, by his voice, raping her. During each of the several sessions on the parrilla, her screams were so high-pitched and continuous that she could not recognise her own voice. After each session she bled from every orifice, including her breasts and her navel. "I didn't give myself permission to feel the pain ... So much electrical current that it's hard to understand that the body can resist it." She was forced to watch her partner being tortured. Some of her many bones smashed by beatings have never healed... " The worst part of torture is not the physical pain that you suffer-I think that the worst part of torture is to have to realise in such a brutal way that human beings are capable of doing something so aberrant to another person as torturing them." ${ }^{24}$

The deeper significance of torture has haunted many of the survivors of Villa Grimaldi and, indeed, once formed part of the interpretation of the site. One survivor guide, fresh from a $\mathrm{PhD}$ at the Sorbonne, explained his horrific experiences in terms of Michel Foucault's Discipline and Punish. ${ }^{25}$ Another, in 2002, wept

24 Read and Wyndham, Narrow but Endlessly Deep, 245.

25 Ibid., I42-43. 
unselfconsciously at the Wall of Names that identified victims of torture each time he took a group of visitors to it. ${ }^{26}$

Resolving to further explore the issue, we discerned a difference between our two "default," or archetypical, victims of torture. The archetype that moved Peter most was female, terrified, weeping, unable to defend herself. Marivic's was male, resistant to pain, racked not only by physical torment but the mental anguish of not being able to exercise his machismo in defending the female torture victim. The long sections in the book on the horrible deaths of Maria Cristina Lopez Stewart and Lumi Videla Moya indicate Peter's insistence on an account of female suffering. ${ }^{27}$

\section{Who Should Carry the Narrative?}

The narrative of each of the seven studies of memorialized sites in the monograph is carried by an individual, such as the entertainer Victor Jara, murdered at the Stadium of Chile (chapter 2), or the sister of a detained-disappeared at Villa Grimaldi (chapter 7). As we began each chapter, we debated which individual, of many protagonists, should be chosen. Marivic felt herself drawn to two in particular because they represented instantly recognizable, deeply felt and respected Latin American character types. One was Nena González, the caretaker of the infamous Patio (precinct) 29 at the National Cemetery, Santiago.

Patio 29 was a remote area in the National Cemetery that in September 1973 held many empty gravesites. To Pinochet's security forces it seemed an ideal location for the hundreds of workers' and students' bodies that they had crammed into trucks with no clear final destination. Into these empty spaces, sometimes two or three within a single grave, the soldiers threw hundreds of corpses. To this day nobody knows how many bodies were disposed of in 1973, nor hurriedly exhumed by the military in 1982, when overseas investigation of their crimes seemed possible. Together with the National Stadium, Patio 29 is among the most infamous and iconic of all the dictatorship atrocity sites. ${ }^{28}$

In the first months of the coup no one was allowed to approach within fifty meters of the precinct-except for the caretaker, Nena González, who occupied the humble and unremunerated position that is handed on through each generation. Terrified, but unobserved or disregarded in contempt, every day she watched the casual discharge of bodies from within her shelter:

Nena: I saw the boxes when they came in twos, when they came naked, when they came stiff as if frozen, and that's not all I saw. I saw everything in the world.... It's a bad comparison, but it's like you had realised that this was

26 Ibid., I37-40.

27 Ibid., II2-20.

28 Cf. Marivic Wyndham and Peter Read, "From State Terrorism to State Errorism: PostPinochet Chile's Long Search for Truth and Justice," The Public Historian 3I, no. I (February 20IO): $3 \mathrm{I}-44$. 


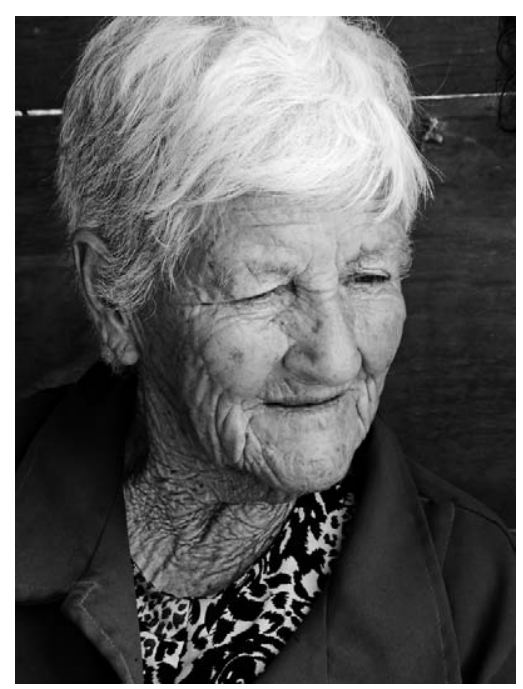

Doña Nena Gonzalez, custodian of Patio 29, General Cemetery Santiago. (Photo by Peter Read)

a slaughterhouse, animals hanging together with the difference that they came in a box. All naked, men and women. And also children. ${ }^{29}$

Today González knows more about Patio 29 than any other Chilean. But her memories are largely disregarded.

In selecting her friend Nena González to carry the narrative of Patio 29, Marivic recognized her as an archetype of her own family: grandmotherly, dignified, without formal education, carrying the wisdom that comes from witnessing decades of violence and civil strife. Peter concurred, even though her prototype was unfamiliar, because the scandalous neglect of González by historians and others was familiar to him through the long tradition of white Australian historians researching and writing Aboriginal history while neglecting actually to consult the Aborigines themselves. Indeed, the lack of attention to her by the Chilean leftist elite could be explained by the closed-off nature of the rigid Chilean class system. We wrote, in mild rebuke,

[Nena] holds so much knowledge, so many memories, so much torment ... but it seems of no value to anyone outside the instant gratification of their curiosity. The deep-seated prejudices of the Chilean class system seem to ensure that few, if any, even those leading the human rights movement, will ever take seriously a 77 -year old woman of bent back and hardly any teeth, in an ancient blue dustcoat. ${ }^{30}$

The following chapter deals with the memorialization of the National Stadium, whose impressive display is the end product of many years of intense debate as to

29 Read and Wyndham, Narrow but Endlessly Deep, 45.

30 Ibid., I85. 


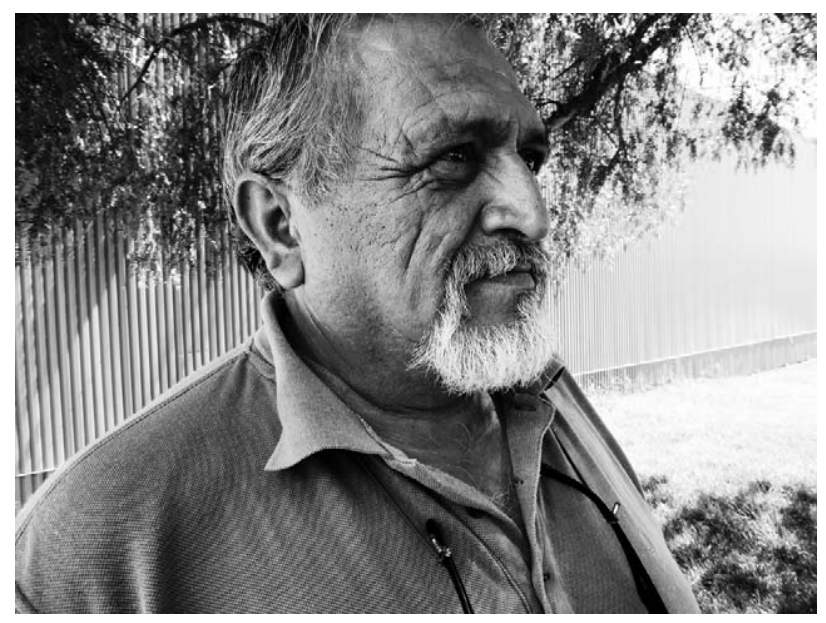

Don Roberto Sanchez, torture victim, National Stadium. To Wyndham he appeared to be the archetypal macho. (Photo by Peter Read)

what, where, and by whom the terrible events should be remembered. The stadium is now the state's principal memorial to the repression. ${ }^{31}$

The second narrator whom Marivic explicitly wanted both had worked and was later a political detainee at this site. In September 1973 Roberto Sanchez was a workman at the National Stadium. Although he sympathized with the left he did not participate in any political party before the coup. Mistakenly arrested on September i6, he became a detainee in the National Stadium where he had been employed only days before, one of more than five thousand men and women held here, tortured, transferred, released, or executed. Detained for several months, tortured at least twice, transferred to a civilian prison for eighteen months, Sanchez at length returned to work in the stadium. In 2016 he was foreman of its National Swimming Centre. Marivic writes that she at once identified Sanchez as a true macho familiar to her family, her school texts, and to her national history: a symbol of male dignity, a defender of honor, stoic but uncomplaining, never yielding. His view of the form that the stadium's memorialization should have taken was very different from that of the memorial architects. All that Sanchez wished for was an unobtrusive fountain near the torture chamber, "just a little plaque, no names no accusations, just water flowing gently over the stones and carved cherubs frolicking in the sunny stream." ${ }^{32}$ Similar to the lack of interest bordering on contempt shown towards Nena González, nobody in the planning committees of the memorialization consulted him, nor even was aware that their swimming pool foreman had been detained and tortured in that very place. In contrast to his understanding of González's significance, Peter was slower to recognize Sanchez as an exemplar of

3I The memorial includes lengthy explanatory plaques, a memorial fountain and sculpture, a walkway to the changing rooms, and the planned restoration of the weights training room used as a torture chamber for the male detainees.

32 Read and Wyndham, Narrow but Endlessly Deep, 79. 
machismo, which in Australia is associated with male aggressive dominance. The nearest Australian archetype familiar to him, the bushman, frequently struggling against unfair destiny, is generally overcome by fate. A nineteenth-century song portrays such a bushman explaining to his horse why they must abandon their pastoral station, Glen Eva:

Come Stumpy old man, we must shift while we can

All the sheep in the paddocks are dead

We must bid our farewells to Glen Eva's sweet dells

and the place where your lordship was bred.

For the banks are all broken they say

And the squatters are all up a tree

When the bigwigs are brought to the bankruptcy court

What chance for a squatter like me? ${ }^{33}$

Peter: Although we followed Sanchez's life trajectory throughout the chapter, I was drawn to a type much more familiar to me, the public historian/curator. At the stadium, Sra Wally Kunstmann had led the long campaign for a professional historical display based on the walk that the detainees took from arrival to the cells to the torture chamber. She battled a hostile press, lukewarm governments, and a variety of contrary proposals, but her design team at length convinced the government to create the memorial almost as it stands today. I wanted to portray her struggle in some detail. Adopting the "double-narrative" strategy similar to what we used in our Cuban research reports, we agreed on two narrators carrying the account of memorialization at the National Stadium. In the final form, Sanchez's experiences and beliefs begin and end the chapter, while the main narrative on what was agreed to by the planning committee and the government is carried by Kunstmann.

\section{Some Final Words}

Relearning outside our cultural boundaries may continue throughout our professional lives, if we allow it. It may come as a sharp shock. In 1988, while lecturing to a group of Papua New Guinean history students in Port Moresby, Peter showed the documentary Secret Country by John Pilger, a stern critic of Australia's Aboriginal policies. ${ }^{34}$ One scene portrayed an Aboriginal woman sprawled on the pavement drinking beer out of half a tin can. Pilger's intention, and Peter's interpretation, was to illustrate the level of degradation to which white Australia had brought her. The reaction of the all-male class of PNG students, however, was disbelief at the woman's

33 "The Broken-Down Squatter," printed in the Australian Poetry Library, http://www .poetrylibrary.edu.au/poets/anon/the-broken-down-squatter-0025022. This argument is developed more fully in Marivic Wyndham and Peter Read, "The Farmer and the Bushman," Environment and History 7, no. I (February 200I): 109-24.

34 John Pilger, Secret Country: The First Australians Fight Back, British Central Independent Television, I985. 
degraded and shameless behavior and blame for Aborigines themselves. "What's wrong with those Aboriginal men? How can they allow their women to behave like that?" Meanwhile Marivic, teaching an advanced Spanish class in 2015, presented to her students the exemplary patriotic Cuban figure of Mariana Grajales. Grajales stands in the pantheon of Cuba's otherwise all-male giants of independence, paradigm of Cuban woman and Cuban mother. She bore thirteen children, mostly male, all groomed for battle. The story is told that Grajales, on being informed of the death in battle of two of her sons, turned to her youngest one saying: "And you, stand up straight. Now it's time for you to go on campaign. One son must replace another."35 Marivic recalls that she had never questioned the morality of Grajales's actions until one of her Australian students demanded, "How can you admire her? She's just like Mrs. Goebbels." I reminded the class and myself of how precepts learnt in childhood can remain unchallenged throughout life.

As we had foreshadowed in the introduction to Narrow but Endlessly Deep, even a statement of intended neutrality might be anathema to certain readers. That proved indeed to be the case. Anxious for an opinion of the draft of Narrow but Endlessly Deep by a Chilean academic, we asked a former MIRista, with whom we had enjoyed friendly and constructive historical conversations for more than a decade, to appraise it. Rejecting it out of hand, he asserted such fundamental disagreement on so many points that he could not comment on it at all. It appeared that he felt betrayed. The relationship, and indeed our friendship, ended at that point.

Never let we public historians underestimate the strength of differing cultural perceptions among those with whom we collaborate and of those whose public history we presume to interpret.

Peter Read is a historian and adjunct professor in the Australian Centre for Indigenous History, Australian National University, Canberra. He is the author of many books of public and Aboriginal history including Returning to Nothing: The Meaning of Lost Places (1996).

Marivic Wyndham is senior lecturer at the School of International Studies, Faculty of Arts \& Social Sciences, University of Technology Sydney. Her historical interests in Latin America include human rights, memorialization, place studies, and testimony. She has also published in Australian cultural history, including A World-Proof Life: Eleanor Dark, a Writer in Her Times (2007).

We acknowledge the assistance of the Australian Research Council in the preparation of this manuscript and the insightful suggestions of two anonymous referees.

35 James D. Henderson, “Mariana Grajales: Black Progenitress of Cuban Independence," Journal of Negro History 63, no. 2 (April I978): $135-53$. 